\title{
MODELLING ANIMAL SYSTEMS RESEARCH PAPER Comparison of responses to dietary protein and lysine in broiler chicks reared before and after 2000 via neural network models
}

\author{
A. FARIDI*, A. GOLIAN AND H. AHMADI \\ Centre of Excellence in the Animal Sciences Department, Ferdowsi University of Mashhad, Mashhad 91775-1163, Iran
}

(Received 19 April 2011; revised 25 January 2012; accepted 12 March 2012; first published online 5 April 2012)

\section{SUMMARY}

The current study was conducted to compare the responses of broiler chicks (average daily gain (ADG) and feed efficiency (FE)) raised before and after 2000 to dietary protein and lysine through neural networks (NN). The available lysine dose-response data were extracted from the literature and arbitrarily divided into two sets of before and after 2000. The training and testing data sets derived from each group were used to develop the NN models. The developed models were subjected to a sensitivity analysis test to assess the relative importance of dietary protein and lysine on chicks' responses. An optimization algorithm was used to find the dietary protein and lysine required for maximum ADG and FE, based on each dataset. The results showed that the NN models developed could predict ADG and FE efficiently in broiler chicks of before and after 2000, and the higher accuracies of prediction were attained by these models compared to those of regression models. Sensitivity analysis indicated that ADG and FE were more sensitive to dietary lysine, compared to protein, in both time periods. Based on the optimization results, the protein and lysine requirements for maximum ADG or FE for birds reared after 2000 were lower and higher, respectively, compared to those reared before 2000. The protein requirements for maximum ADG and FE for birds reared before 2000 were 241.3 and $247.0 \mathrm{~g} / \mathrm{kg}$ diet and for lysine $10.76 \mathrm{and} 11.18 \mathrm{~g} / \mathrm{kg}$ diet, respectively. In birds reared after 2000, maximum ADG was obtained when the diet contained 224.30 g protein/ $\mathrm{kg}$ diet and $11.75 \mathrm{~g}$ lysine $/ \mathrm{kg}$ diet, whereas maximum FE was achieved with a diet containing $228.3 \mathrm{~g}$ protein and $13 \cdot 1 \mathrm{~g}$ lysine.

\section{INTRODUCTION}

There is special concern in determining lysine requirements of broiler chickens due to its role as a second limiting amino acid in the improvement of daily weight gain, feed efficiency (FE) and breast meat yield. Moreover, lysine is used as a reference amino acid in an ideal protein concept. Broiler chicken responses to indispensable amino acids may vary depending on dietary protein and energy, genetic strain, sex, experimental conditions and the statistical methods applied. Dietary protein level is one of the most important factors affecting lysine requirement. The relationship between lysine and protein requirements for optimum growth has been reported in many studies (Almquist 1952; Boomgaardt \& Baker 1973; Sterling et al. 2003; Abdel-Maksoud et al. 2010). Genetic selections

* To whom all correspondence should be addressed. Email: ako_faridi@yahoo.com applied by industry have greatly increased growth rate and yield of edible meat, while reducing feed conversion ratio and the slaughter age of modern broiler chickens, thus influencing nutrient requirements (Dozier et al. 2001; Fancher 2006). Although there are several recommendations for amino acid requirements, it is still difficult to choose the most advantageous dietary amino acid pattern, partly due to nonlinearity of growth responses to changes in amino acids (Mercer 1982; MacLeod 2000), interactions between or among amino acids, antagonism or toxicity (D'Mello 1994), and interactions of some amino acids with other nutrients or anti-nutritive factors (Austic 1986).

There is an ever-increasing body of information on lysine requirements of broiler chickens that can be used to make reliable general recommendations for this amino acid. Mathematical models can be used to integrate the available knowledge on nutrient 


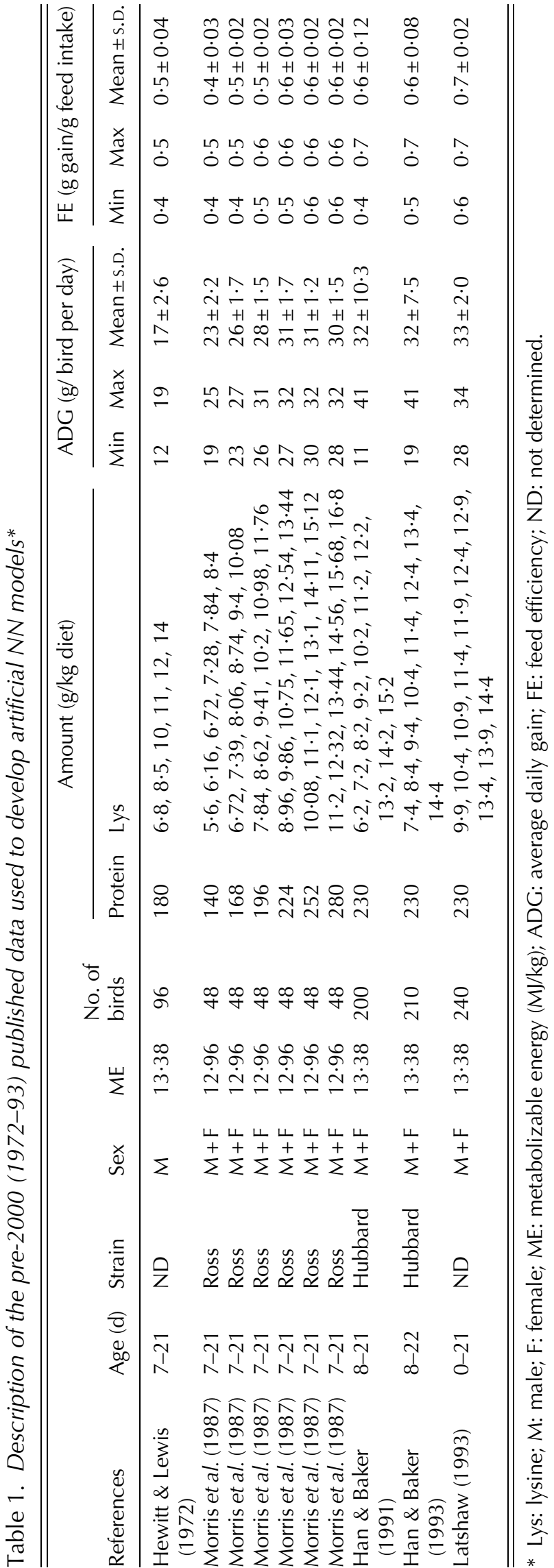

utilization, performance and carcass characteristics of broiler chickens (Ahmadi \& Golian 2010). In this way, using the potential of non-linear data-mining tools such as neural networks (NN) is constructive. An NN model is a biologically inspired computing scheme that can uncover highly complex relationships between several input and output variables. This approach has been applied successfully in several fields of broiler chicken production (Ahmadi \& Golian 2010; Faridi et al. 2011, 2012). The objectives of the current study were to: (i) compare the responses of two separate groups of pre- and post-2000 broiler chicks to protein and lysine through $\mathrm{NN}$; (ii) determine the relative importance of protein and lysine on average daily gain (ADG) and FE using a sensitivity analysis test; (iii) find the optimum level of dietary protein and lysine required to maximize ADG and FE of chicks in the two time periods; and (iv) compare the predictive ability of NN models with that of classical regression models.

\section{MATERIALS AND METHODS}

\section{Description of data}

One hundred and eighty lines of broiler chicks' dose responses (ADG and $\mathrm{FE}$ ) to protein and lysine were extracted from the literature and arbitrarily divided into two sets of 104 and 76 data lines of pre- and post-2000, respectively. The experiments of pre-2000 were conducted during 1972-93, while post-2000 were conducted from 2000-10. A mixed-sex total of 10262 birds from Ross, Cobb and Hubbard commercial strains were used in both time periods. The data were collected using the following criteria:

1. They appeared in peer-reviewed published articles.

2. The levels of lysine were solely used as treatments, except for Costa et al. (2001c) in which different levels of protein were considered as treatments.

3. The dietary levels of lysine (total lysine) and protein were clearly defined.

4. The ADG (g/bird per day) and FE (g gain/g feed intake) were reported or could be calculated.

5. The experiments published after 2000 were conducted over 0-21 days of age, with the exceptions of Abdel-Maksoud et al. (2010) and Kidd \& Fancher (2001) in which the period was from 0 to 18 days and Sterling et al. (2006) in which it was 7-21 days, whereas all experiments published before 2000 were conducted over 7-21 days of age, except for Latshaw (1993) who used 0-21 days of age. 
Table 2. Description of the post-2000 (2000-10) published data used to develop artificial NN models*

\begin{tabular}{|c|c|c|c|c|c|c|c|c|c|c|c|c|c|}
\hline \multirow[b]{2}{*}{ References } & \multirow[b]{2}{*}{ Age (d) } & \multirow[b]{2}{*}{ Strain } & \multirow[b]{2}{*}{ Sex } & \multirow[b]{2}{*}{ ME } & \multirow{2}{*}{$\begin{array}{l}\text { No. of } \\
\text { birds }\end{array}$} & \multicolumn{2}{|c|}{ Amount (g/kg diet) } & \multicolumn{3}{|c|}{ ADG (g/ bird per day) } & \multicolumn{3}{|c|}{ FE (g gain/g feed intake) } \\
\hline & & & & & & Protein & Lys & Min & Max & Mean \pm S.D. & Min & Max & Mean \pm S.D. \\
\hline Barboza et al. (2000) & $1-21$ & Ross, Hubbard & $M+F$ & $12 \cdot 75$ & 1920 & $226 \cdot 1$ & $\begin{array}{r}10,10 \cdot 6,11 \cdot 2 \\
11 \cdot 8,12 \cdot 4,13\end{array}$ & 28 & $37 \cdot 7$ & $33 \pm 2 \cdot 5$ & $0 \cdot 63$ & $0 \cdot 69$ & $0 \cdot 66 \pm 0 \cdot 017$ \\
\hline Costa et al. (2001C) & $1-21$ & Ross & $M+F$ & $12 \cdot 75$ & 240 & 200 & $12 \cdot 9$ & 30 & $31 \cdot 9$ & $31 \pm 1 \cdot 1$ & $0 \cdot 63$ & $0 \cdot 64$ & $0 \cdot 63 \pm 0 \cdot 012$ \\
\hline Costa et al. (2001C) & $1-21$ & Ross & $M+F$ & $12 \cdot 75$ & 240 & 205 & 13 & $30 \cdot 3$ & $31 \cdot 3$ & $30 \cdot 8 \pm 0 \cdot 73$ & $0 \cdot 64$ & $0 \cdot 65$ & $0 \cdot 64 \pm 0 \cdot 005$ \\
\hline Costa et al. (2001c) & $1-21$ & Ross & $M+F$ & $12 \cdot 75$ & 240 & 210 & $13 \cdot 4$ & 30 & 32 & $31 \pm 1 \cdot 5$ & $0 \cdot 64$ & $0 \cdot 66$ & $0 \cdot 65 \pm 0 \cdot 011$ \\
\hline Costa et al. (2001c) & $1-21$ & Ross & $M+F$ & $12 \cdot 75$ & 240 & 215 & $13 \cdot 1$ & $31 \cdot 8$ & $32 \cdot 8$ & $32 \cdot 3 \pm 0 \cdot 73$ & $0 \cdot 66$ & $0 \cdot 67$ & $0 \cdot 67 \pm 0 \cdot 014$ \\
\hline Costa et al. (2001c) & $1-21$ & Ross & $M+F$ & $12 \cdot 75$ & 240 & 220 & $13 \cdot 4$ & $31 \cdot 4$ & $31 \cdot 7$ & $31 \cdot 6 \pm 0 \cdot 16$ & $0 \cdot 66$ & $0 \cdot 67$ & $0 \cdot 67 \pm 0.006$ \\
\hline Costa et al. (2001c) & $1-21$ & Ross & $M+F$ & $12 \cdot 75$ & 240 & 225 & $13 \cdot 4$ & $31 \cdot 5$ & $32 \cdot 0$ & $31 \cdot 7 \pm 0 \cdot 33$ & $0 \cdot 66$ & $0 \cdot 67$ & $0 \cdot 66 \pm 0 \cdot 006$ \\
\hline Costa et al. (2001b) & $1-21$ & Ross & $M+F$ & $12 \cdot 54$ & 1440 & 220 & $\begin{array}{r}10 \cdot 3,10 \cdot 9,11 \cdot 5 \\
12 \cdot 1,12 \cdot 7,13 \cdot 3\end{array}$ & $30 \cdot 3$ & $32 \cdot 8$ & $31 \cdot 5 \pm 0 \cdot 84$ & $0 \cdot 63$ & $0 \cdot 67$ & $0 \cdot 65 \pm 0 \cdot 014$ \\
\hline Kidd \& Fancher (2001) & $1-18$ & Ross & $M+F$ & $12 \cdot 96$ & 2000 & 215,216 & $\begin{array}{c}8 \cdot 8,9 \cdot 9,11,12 \cdot 1 \\
13 \cdot 2,14 \cdot 3\end{array}$ & 19 & 32 & $27 \pm 4 \cdot 2$ & $0 \cdot 53$ & $0 \cdot 71$ & $0 \cdot 66 \pm 0 \cdot 017$ \\
\hline Corzo \& Kidd (2004) & $1-21$ & ND & $\mathrm{F}$ & $12 \cdot 85$ & 480 & 220 & $12,13 \cdot 5$ & $26 \cdot 1$ & $28 \cdot 1$ & $27 \cdot 4 \pm 0 \cdot 75$ & $0 \cdot 7$ & $0 \cdot 8$ & $0 \cdot 7 \pm 0 \cdot 02$ \\
\hline Sterling et al. (2006) & $7-21$ & Ross, Cobb & $M$ & $13 \cdot 38$ & 288 & 170,230 & $6,7,8,9$ & 13 & 22 & $17 \pm 2 \cdot 7$ & $0 \cdot 4$ & $0 \cdot 7$ & $0 \cdot 6 \pm 0 \cdot 07$ \\
\hline Safamehr et al. (2008) & $1-21$ & Ross & $M+F$ & $12 \cdot 54$ & 400 & $215 \cdot 6$ & $\begin{array}{l}10 \cdot 3,11 \cdot 3,11 \cdot 8 \\
12 \cdot 3,12 \cdot 8\end{array}$ & 32 & 37 & $24 \pm 2 \cdot 1$ & $0 \cdot 61$ & $0 \cdot 68$ & $0 \cdot 64 \pm 0 \cdot 029$ \\
\hline $\begin{array}{l}\text { Abdel-Maksoud et al. } \\
\text { (2010) }\end{array}$ & $0-18$ & Cobb & $M$ & $12 \cdot 86$ & 1260 & $\begin{array}{l}190,210 \\
230\end{array}$ & $\begin{array}{c}11,11 \cdot 5,12,12 \cdot 5 \\
13,13 \cdot 5,14\end{array}$ & 31 & 36 & $35 \pm 1 \cdot 4$ & $0 \cdot 63$ & $0 \cdot 74$ & $0 \cdot 7 \pm 0 \cdot 023$ \\
\hline
\end{tabular}

* Lys: lysine; M: male; F: female; ME: metabolizable energy (MJ/kg); ADG: average daily gain; FE: feed efficiency; ND: not determined. 
Table 3. The ranges of data used to develop the NN models for pre- and post-2000 chicks' responses to protein and lysine*

\begin{tabular}{lccccccc}
\hline \hline & \multicolumn{3}{c}{ Chicks reared before 2000} & & \multicolumn{3}{c}{ Chicks reared after 2000 } \\
\cline { 2 - 3 } Entityt & Min & Max & Mean \pm S.D. & & Min & Max & Mean \pm S.D. \\
\hline Protein (g/kg diet) & 140 & 280 & $216 \pm 36 \cdot 2$ & & 170 & 230 & $216 \pm 15 \cdot 3$ \\
Lysine (g/kg diet) & 6 & $16 \cdot 8$ & $11 \pm 2 \cdot 6$ & & 6 & 14 & $12 \pm 1 \cdot 9$ \\
ADG (g/bird per day) & 11 & 41 & $29 \pm 6 \cdot 7$ & & 13 & $37 \cdot 7$ & $30 \pm 5 \cdot 8$ \\
FE (g gain/g feed intake) & $0 \cdot 39$ & $0 \cdot 74$ & $0 \cdot 57 \pm 0 \cdot 093$ & & $0 \cdot 40$ & $0 \cdot 75$ & $0 \cdot 66 \pm 0 \cdot 062$ \\
ME (M)/kg) & $13 \cdot 0$ & $13 \cdot 4$ & $13 \cdot 2 \pm 0 \cdot 21$ & & $12 \cdot 5$ & $13 \cdot 4$ & $12 \cdot 9 \pm 0 \cdot 26$ \\
\hline \hline
\end{tabular}

* Before 2000 refers to 1972-93 and after 2000 refers to 2000-10.

+ ADG: average daily gain; FE: feed efficiency; ME: metabolizable energy.

Table 4. Statistics and information for the development of NN models to estimate ADG and FE of birds reared before and after 2000*

\begin{tabular}{|c|c|c|c|c|c|c|c|c|}
\hline \multirow[b]{3}{*}{ Entity } & \multicolumn{4}{|c|}{ Chicks reared before 2000} & \multicolumn{4}{|c|}{ Chicks reared after 2000} \\
\hline & \multicolumn{2}{|l|}{ ADG } & \multicolumn{2}{|c|}{$\mathrm{FE}$} & \multicolumn{2}{|c|}{ ADG } & \multicolumn{2}{|c|}{$\mathrm{FE}$} \\
\hline & Training & Testing & Training & Testing & Training & Testing & Training & Testing \\
\hline \multicolumn{9}{|l|}{ Statistics } \\
\hline$R^{2}$ & $0 \cdot 9$ & $0 \cdot 87$ & 0.97 & 0.93 & $0 \cdot 86$ & $0 \cdot 86$ & $0 \cdot 88$ & $0 \cdot 76$ \\
\hline MSE & $5 \cdot 16$ & $6 \cdot 97$ & $0 \cdot 0002$ & $0 \cdot 0005$ & $5 \cdot 46$ & $3 \cdot 97$ & $0 \cdot 0003$ & $0 \cdot 001$ \\
\hline Bias & $0 \cdot 046$ & $-1 \cdot 03$ & $0 \cdot 0003$ & $-0 \cdot 005$ & $0 \cdot 058$ & $-0 \cdot 11$ & $0 \cdot 0007$ & -0.002 \\
\hline \multicolumn{9}{|l|}{ Information } \\
\hline Type of network & \multicolumn{8}{|c|}{ Three-layer perceptron } \\
\hline Training algorithm & \multicolumn{8}{|c|}{ Quasi-Newtonian } \\
\hline No. of hidden neurons & \multicolumn{2}{|c|}{8} & \multicolumn{2}{|c|}{7} & \multicolumn{2}{|c|}{5} & \multicolumn{2}{|c|}{7} \\
\hline No. of data lines & 50 & 26 & 50 & 26 & 52 & 52 & 52 & 52 \\
\hline
\end{tabular}

* Before 2000 refers to 1972-93 and after 2000 refers to 2000-10; MSE: mean square error.

The data used to develop NN models for ADG and FE of broiler chicks reared pre- and post-2000 are summarized in Tables 1 and 2, respectively.

\section{NN model development}

Determining an appropriate network topology is one of the most critical tasks in NN model development. The NN's topology is determined by its size, synaptic weight connections and the hidden-units activation function (Andrews et al. 2008). In the current study, four feed-forward multilayer perceptrons, each with protein ( $\mathrm{g} / \mathrm{kg}$ diet) and lysine ( $\mathrm{g} / \mathrm{kg}$ diet) as input variables, were employed to predict ADG and FE in chicks raised in either time period. The configuration of all developed models consisted of only one hidden layer. In all the models developed, the hyperbolic tangent was considered as an activation function, whereas the
quasi-Newton method was used as a training algorithm and two different random data groups were considered in developing models. The first group was the training set and used for updating the network weights and biases, and the remainder was used as the testing set. The range of data used to develop the models during both time periods is summarized in Table 3 . The Statistica Neural Networks software version 8.0 was used to construct and train the $\mathrm{NN}$ models (StatSoft 2009). Quantitative examination of the predictive ability of both models was made by $R^{2}$, mean square error and bias.

Sensitivity analysis

A sensitivity analysis technique indicates the input variables that are considered as the most important variables in the developed model. This often 


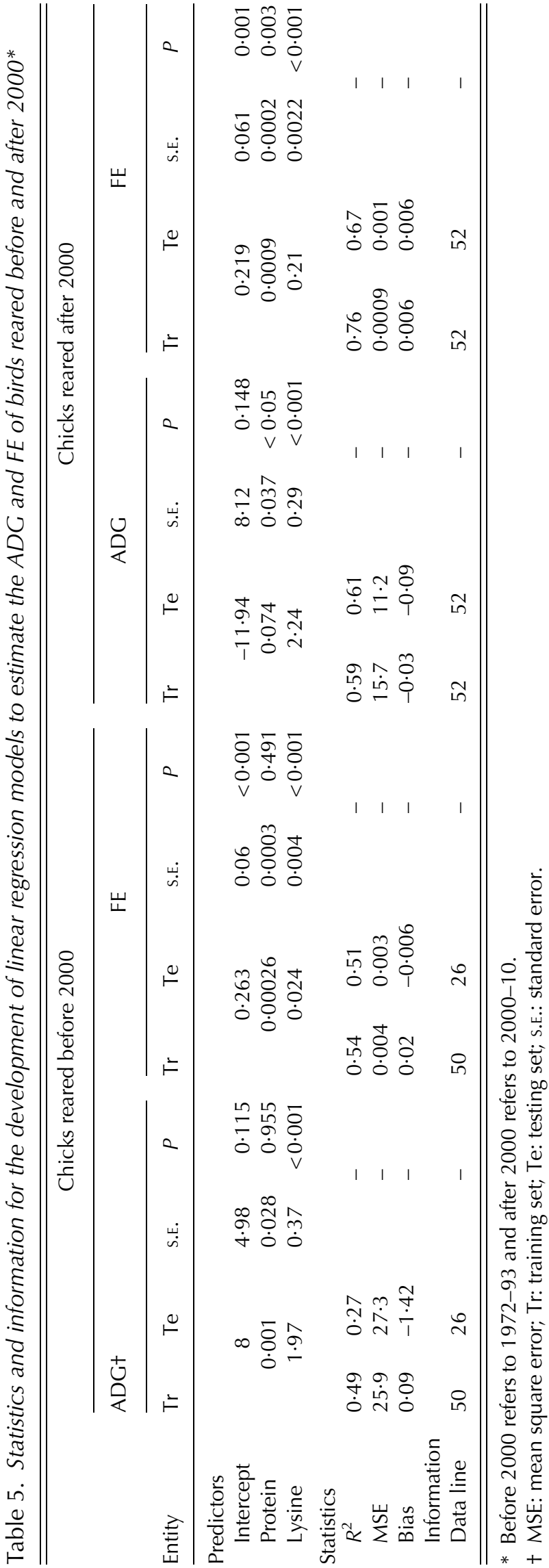

identifies variables that can be safely ignored in subsequent analysis, and key variables that must always be retained (Faridi et al. 2012). There are several approaches for conducting sensitivity analyses. The sensitivity of response models to protein and lysine as input variables was determined by the missing value problem proposed by Hunter et al. (2000); in this method each input variable is replaced in turn with missing values and the effect upon the output error, named variable sensitivity error (VSE), is assessed. By the same token, the variable sensitivity ratio (VSR) is a relative indication of the ratio between the VSE and the error of the developed model when all variables are available. The more important variable is matched with the higher VSR (Lou \& Nakai 2001; Ahmadi \& Golian 2010).

\section{Model optimization}

Optimization is defined as finding a set of values for input variables in which the predictive model yields the desired responses. Therefore, the optimized ADG and FE models describe the levels of dietary protein and lysine required for maximum $\mathrm{ADG}$ and FE. The random search method, a common optimization method provided in the Statistica software (StatSoft 2009), was applied to the models developed. In this method, iterative random samples of the input variables are taken and model prediction is computed and compared with the best value found from the previous iterations. If the newly found value is better than the previous one, the new results are stored. This process is repeated until the end of iterations is reached. The random search should be confined to the data range in which the models were developed, otherwise it may lead to unreliable results.

\section{Regression models}

Conventional linear regression models were compared to the NN models. The data investigated were subjected to linear regression analysis using the REG procedure of SAS (1999). Both dietary protein and lysine levels were considered in developing regression models for ADG and FE responses. The regression models were developed based on the same training data used to develop NN models, and the testing sets were used to evaluate the performance of the regression models. 

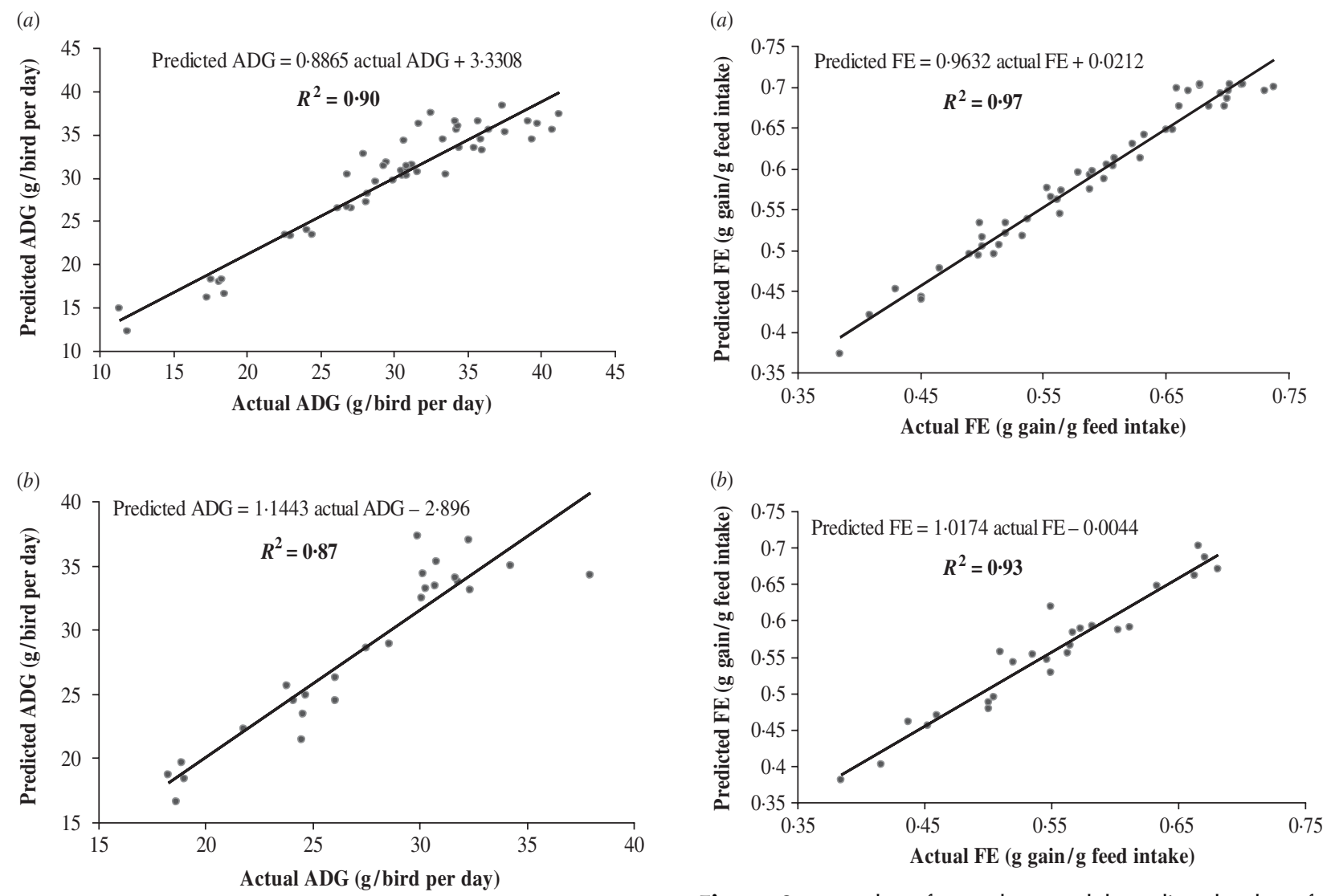

Fig. 1. Scatter plot of actual $v$. model-predicted values for ADG (g/bird per day) for pre-2000 chicks (1972-93; black dots). (a) Training set $(n=50)$; (b) testing set $(n=26)$. The solid line shows the simple regression line fitted on the scatter points.

\section{RESULTS}

The statistics and information used to develop the NN and regression models to study the responses of chicks reared before and after 2000 are shown in Tables 4 and 5, respectively. The NN models showed a higher coefficient of determination compared to that of the regression models. The calculated values of goodness of fit indicated that in all developed NN models, the training sets provided higher values of $R^{2}$ than those in the testing sets, with the exception of the ADG model for chicks raised after 2000, in which a similar value of $R^{2}$ in both training and testing sets was achieved (Table 4). As measured by bias, all the developed models showed very little over- and under-estimation of ADG and FE for broiler chicks.

Scatter plots of NN models for actual $v$. predicted values of ADG and FE for chicks reared before and after 2000 are shown in Figs. 1-4, respectively. Moreover, based on the developed NN models using a distance-weighed least squares fitting method, 4

Fig. 2. Scatter plot of actual $v$. model-predicted values for FE (g gain/g feed intake) for pre-2000 chicks (1972-93; black dots). (a) Training set $(n=50)$; (b) testing set $(n=26)$. The solid line shows the simple regression line fitted to the scatter points.

three-dimensional graphs were generated to show the responses of chicks to simultaneous changes in protein and lysine (Figs. 5-8).

The relative importance of the input variables to broiler responses was determined using a sensitivity analysis test. The sensitivity analysis results for all of the $\mathrm{NN}$ models indicated that the responses of broiler chicks (ADG and FE) were more sensitive to dietary lysine (VSR $=6.64$ and 7.31 for ADG and FE of pre2000 and 8.38 and 9.8 for post-2000, respectively) than to protein $(\mathrm{VSR}=6.4$ and 6.74 for $\mathrm{ADG}$ and FE of pre-2000 chicks, and 2 and 3.7 for post-2000 chicks, respectively; Table 6).

The optimization results for all the developed models during two time periods are summarized in Table 7. The ranges of protein and lysine in the optimization process were the same as the ranges used to develop the model (Table 3). The optimization of models developed based on the data published before 2000 indicated that maximum ADG $(32.6 \mathrm{~g} / \mathrm{bird}$ per day) and FE (0.594 g gain/g feed intake) were achieved 

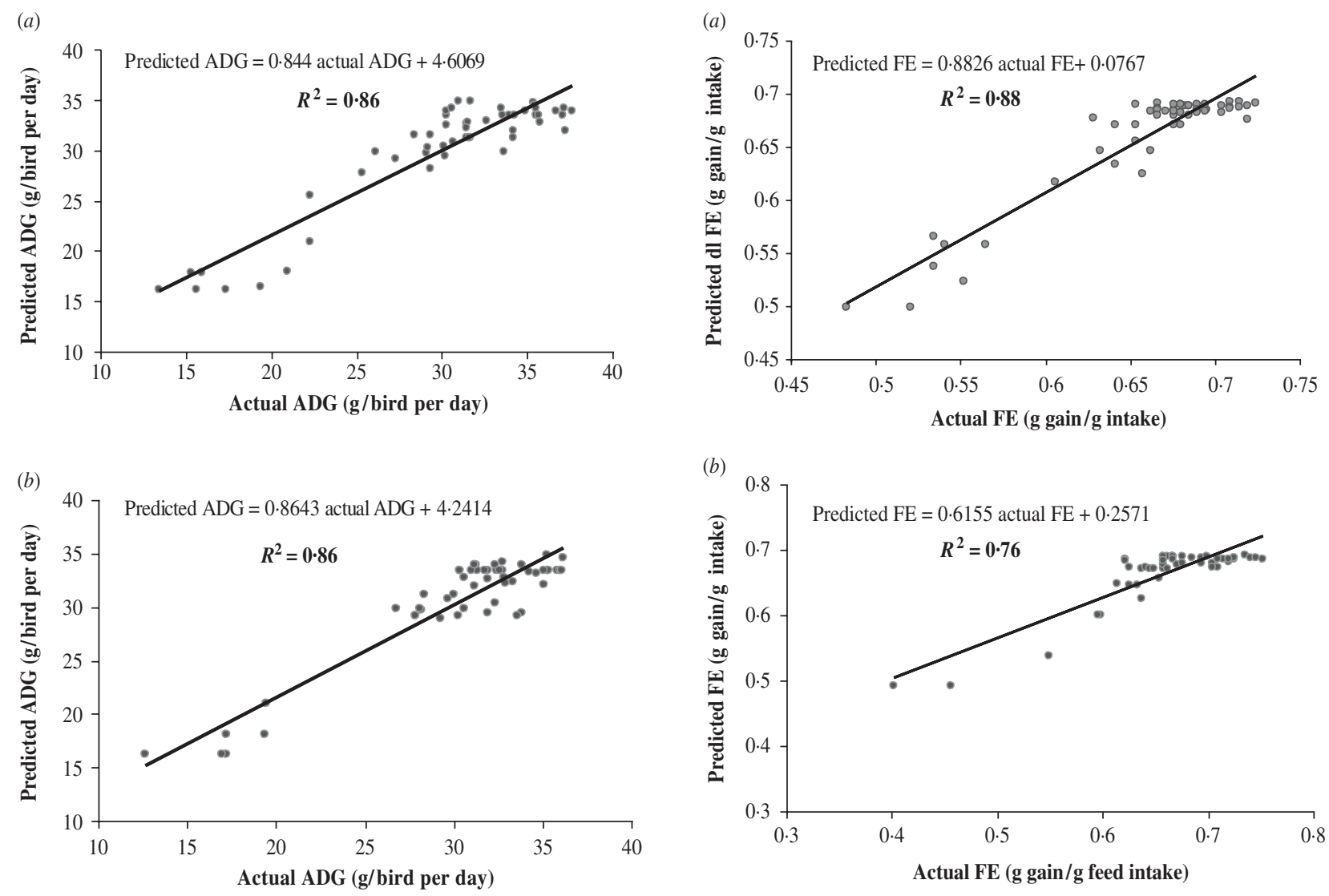

Fig. 3. Scatter plot of actual $v$. model-predicted values for ADG (g/bird per day) for post-2000 chicks (2000-10; black dots). (a) Training set $(n=52)$; (b) testing set $(n=52)$. The solid line shows the simple regression line fitted to the scatter points.

with diets containing 241.3 and $247 \mathrm{~g}$ protein and $10 \cdot 76$ and $11 \cdot 18 \mathrm{~g}$ lysine/kg diet, respectively. Based on the data published after 2000, maximum ADG (33 g/bird/day) and FE (0.692 g gain $/ \mathrm{g}$ feed intake) were obtained with diets containing 224.3 and $228.3 \mathrm{~g}$ protein and 11.75 and $13.1 \mathrm{~g}$ lysine/ $\mathrm{kg}$ diet, respectively. These results indicate that the optimum dietary protein levels to maximize ADG and FE in chicks reared after 2000 were lower than for those reared before 2000 .

\section{DISCUSSION}

In the current study, NN models were developed to investigate the response of broiler chicks to dietary protein and lysine in data groups covering two different time periods. The prediction ability of the NN models was compared with that obtained from the regression models. The results indicated that the NNbased estimation technique for chicks' responses to

Fig. 4. Scatter plot of actual $v$. model-predicted values for FE (g gain/g feed intake) for post-2000 chicks (2000-10; black dots). (a) Training set $(n=52)$; (b) testing set $(n=52)$. The solid line shows the simple regression line fitted to the scatter points.

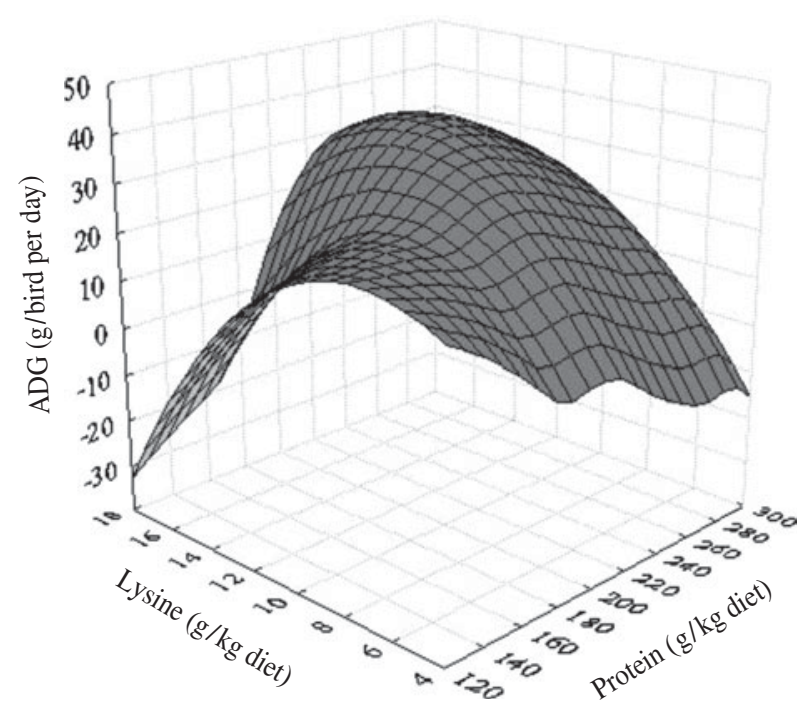

Fig. 5. Distance-weighted least squares plot of changes in model predicted values of ADG (g/bird per day) for pre2000 (1972-93) chicks fed diets different levels of protein and lysine. 


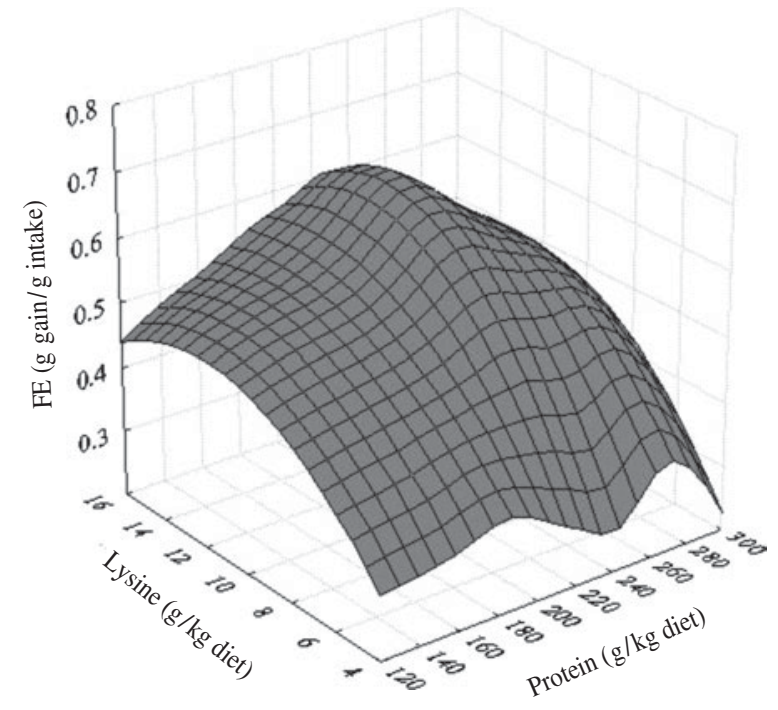

Fig. 6. Distance-weighted least squares plot of changes in model predicted values of FE (g gain/g feed intake) for pre2000 (1972-93) chicks fed diets different levels of protein and lysine.

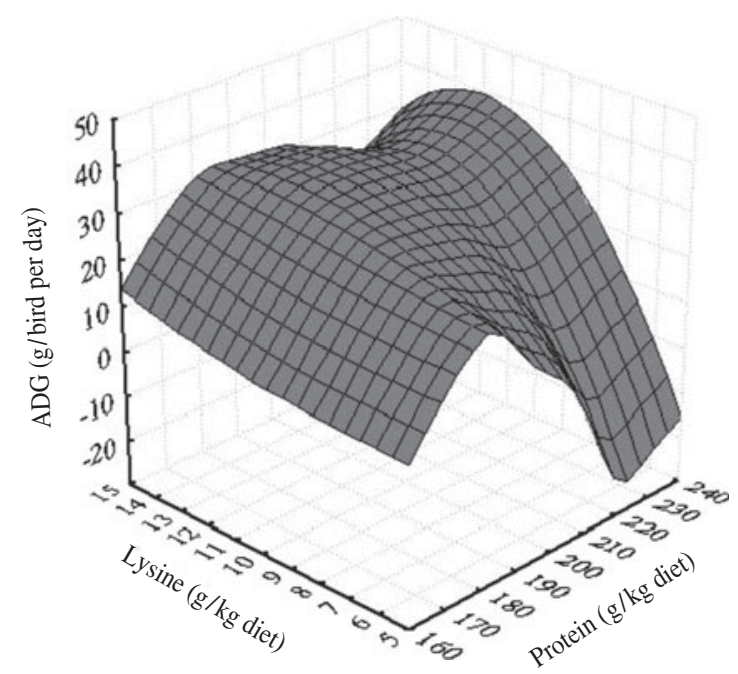

Fig. 7. Distance-weighted least squares plot of changes in model predicted values of ADG (g/bird per day) for post2000 (2000-10) chicks fed diets different levels of protein and lysine.

protein and lysine is more suitable than conventional regression analysis, partly due to the non-linear responses of chicks to protein and lysine.

In the current study, the calculated values of VSE and VSR were considered as criteria to determine the relative importance of protein and lysine on model output (ADG and FE). The input variables with VSR $\leqslant 1$ can be safely ignored in the model development, whereas a higher value of VSR indicates a more
Table 6. Overall sensitivity analysis of input variables in the NN models for the ADG and FE during the starter period for chicks reared in two time periods

\begin{tabular}{lll}
\hline \hline & \multicolumn{2}{c}{ Input variables } \\
\cline { 2 - 3 } & $\begin{array}{l}\text { Protein } \\
\text { (g/kg diet) }\end{array}$ & $\begin{array}{l}\text { Lysine } \\
\text { (g/kg diet) }\end{array}$ \\
\hline Model* & & \\
\hline Chicks reared before 2000 & & \\
ADG & $6 \cdot 40$ & $6 \cdot 64$ \\
VSRt & 2 & 1 \\
Rank & & \\
FE & $6 \cdot 74$ & $7 \cdot 31$ \\
VSR & 2 & 1 \\
Rank & & \\
Chicks reared after 2000 & & $8 \cdot 38$ \\
ADG & $2 \cdot 00$ & 1 \\
VSR & 2 & $9 \cdot 80$ \\
Rank & & 1 \\
FE & $3 \cdot 70$ & \\
VSR & 2 & \\
Rank & & \\
\hline \hline
\end{tabular}

* Before 2000 refers to 1972-93 and after 2000 refers to 2000-10.

+ VSR: variable sensitivity ratio.

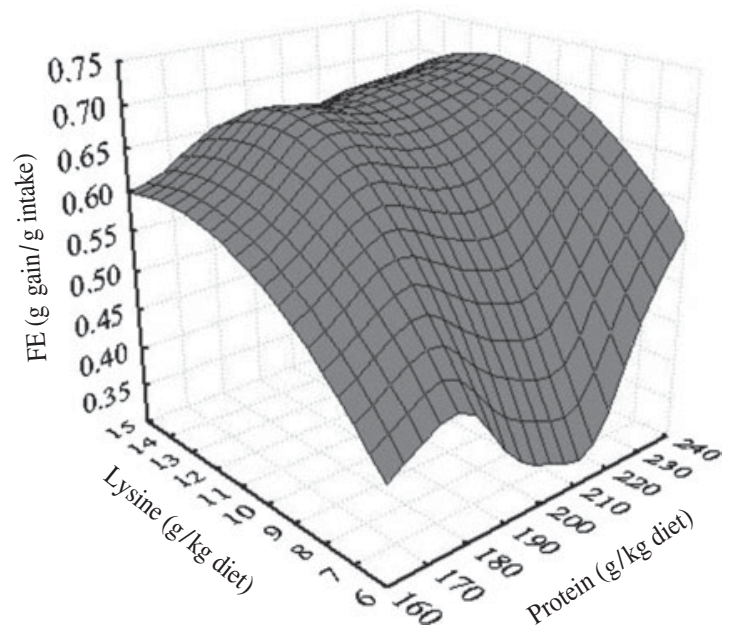

Fig. 8. Distance-weighted least squares plot of changes in model predicted values of (FE (g gain/g feed intake) for post-2000 (2000-10) chicks fed diets different levels of protein and lysine.

important variable in the developed model. In all of the developed NN models, the calculated values of VSR for protein and lysine were $>1$, which indicates the significant influence of dietary protein and lysine levels on the performance of chicks. Similar findings have been reported by other researchers investigating 
Table 7. Optimization analysis of the artificial NN models to achieve maximum ADG and FE in the starter period for chicks reared in two time periods

\begin{tabular}{llll}
\hline \hline & \multicolumn{2}{c}{ Optimal value of input variable } & \\
\cline { 2 - 3 } Model* & Protein $(\mathrm{g} / \mathrm{kg}$ diet $)$ & Lysine $(\mathrm{g} / \mathrm{kg}$ diet $)$ & Predicted output variable at optimal point \\
\hline $\begin{array}{l}\text { Chicks reared before 2000 } \\
\text { ADG }\end{array}$ & $241 \cdot 3$ & & \\
$\quad$ FE & $247 \cdot 0$ & $10 \cdot 76$ & Maximum ADG $=32 \cdot 6 \mathrm{~g} / \mathrm{bird}$ per day \\
$\begin{array}{l}\text { Chicks reared after 2000 } \\
\text { ADG }\end{array}$ & $11 \cdot 18$ & Maximum FE $=0 \cdot 594 \mathrm{~g}$ gain $/ \mathrm{g}$ feed intake \\
FE & $224 \cdot 3$ & $11 \cdot 75$ & Maximum ADG $=33 / \mathrm{bird}$ per day \\
\hline \hline
\end{tabular}

* Before 2000 refers to 1972-93 and after 2000 refers to 2000-10.

the response of broiler chicks to dietary protein and lysine (Sterling et al. 2002, 2003). However, the weight for dietary protein and lysine on the responses of chicks usually depends on the experimental design and the statistical methods. The sensitivity analysis of the $\mathrm{NN}$ models developed for two time periods showed that the response of broiler chicks was more sensitive to lysine than to protein. In accordance with the current findings, Gous \& Morris (1985) stated that chick growth is strictly a function of the first limiting amino acid and is not influenced by protein intake. The higher sensitivity of chicks' growth and FE to lysine in the models developed may be proof of the postulated concept to 'decrease the levels of dietary protein and balance the most critical essential amino acids in order to decrease the dietary costs and the nitrogen excretion to environment' (Lopez \& Leeson 1995; Kidd et al. 1996). Nitrogen retention efficiency can be increased by feeding a low protein diet supplemented with essential amino acids in a pattern that meets maintenance and tissue accretion requirements.

Simultaneous changes in protein and lysine levels while tracking the responses of chicks can help nutritionists evaluate the combined effects of protein and lysine (Figs. 5-8). In each graph, the variation in dietary protein and lysine is considered in the range of the experimental dataset. Based on these figures, the highest values of ADG and FE can be achieved at the high levels of dietary protein and lysine. However, at the low levels of dietary protein, the increased lysine had a more pronounced effect on ADG and FE compared to the increased protein at low lysine levels. Therefore, the models developed show that the chicks' responses are more sensitive to lysine than to protein.
One of the most useful applications of the NN models is to subject them to the optimization process to find the optimum level of input variables (protein and lysine requirements), which would lead to the desired responses. Optimization results for the models developed based on the data published before 2000 indicated that maximum ADG and FE were achieved with diets containing 241.3 and $247 \mathrm{~g}$ protein and 10.76 and $11.18 \mathrm{~g}$ lysine $/ \mathrm{kg}$ diet, respectively. A wide range of lysine, from 8.5 (Hewitt \& Lewis 1972) to $14 \cdot 1 \mathrm{~g} / \mathrm{kg}$ diet (Han \& Baker 1991) has been suggested in the literature to achieve maximum ADG and FE. Such differences in lysine recommendations may be due to differences in the genetics, environments and dietary factors in those experiments. The optimization results for the models developed from post-2000 data indicated that maximum ADG and FE could be obtained with diets containing 224.3 and $228.3 \mathrm{~g}$ protein and 11.75 and $13.1 \mathrm{~g}$ lysine/kg diet, respectively. The lysine requirement of 11.74 (Barboza et al. 2000) to $13 \cdot 5 \mathrm{~g} / \mathrm{kg}$ diet (Corzo \& Kidd 2004) was suggested for the chicks raised after 2000. However, the optimum level of dietary lysine to maximize performance is influenced by dietary protein level and amino acid balance (Abdel-Maksoud et al. 2010). The results of the current study indicated that the optimum level of dietary lysine for chicks reared after 2000 was higher than that suggested by NRC (1994) for maximum weight gain $(11.75 \mathrm{v} .11 \mathrm{~g} / \mathrm{kg})$ and FE $(13.1 \mathrm{v} .11 \mathrm{~g} / \mathrm{kg})$ with the starter diet.

The optimization results showed that the optimum dietary protein to maximize ADG and FE in chicks reared after 2000 was lower than for those reared before 2000, while the requirement for lysine, which increases protein synthesis and decreases protein degradation in chicks, was higher. The change in lysine 
requirement may be due to the genetic alterations of meat-type birds through breeding programmes (Kidd \& Fancher 2001); therefore genetic alteration may be the reason for the higher lysine requirement found in the current study in broiler chicks reared after 2000 as compared to those reared before 2000 .

Although more data are required to confirm this hypothesis, due to similar ADG for chicks reared after and before 2000 ( 33 v. 32.6 g/bird per day) and higher values of FE for those reared after $2000(0.692 \mathrm{~V}$. $0.594 \mathrm{~g}$ gain/g food intake), it is postulated that the genetic selection pressure applied by the breeder companies during previous decades was focused more on FE than on ADG. Similarly, Sterling et al. (2006) stated that breeding companies had focused on improving FE and higher meat yields in the previous decade. It should be noted that the main proportion of data collected after 2000 was from 1 to 21 days of age, whereas the bulk of data collected for birds of before 2000 was from 7 to 21 days of age, which may have caused the equal ADG for chicks of the two time periods. Moreover, the high protein requirement found for broilers raised before 2000 might be true because of the complex and low-quality ingredients used pre2000 compared with recent maize-soy diets. From the animal nutrition point of view, plant breeders have tried to produce high-quality plants with: minimum use of resources (e.g. water, fossil energy, etc.), increased resistance to pests, low anti-nutritional factors and an increase in the bioavailability of nutrients such as amino acids, fatty acids and minerals (Flachowsky et al. 2005). Moreover, the use of new techniques (genetic engineering) to modify the genetic makeup of plants has led to a new generation of genetically modified plants with improved nutritive values. Lucas et al. (2007) compared the nutritional value of lysine maize (genetically modified maize with high levels of lysine) and conventional maize in broiler diets and concluded that the genetically modified maize can be more nutritious than conventional maize, without any unexpected effects on bird health or performance.

The current results indicated that the protein and lysine requirements suggested by the $\mathrm{NN}$ models to maximize $\mathrm{FE}$ were relatively higher than those for ADG. Similarly, Han \& Baker (1993) and Leclercq (1998) reported that the lysine requirement for feed conversion is higher than that for weight gain in broiler chicks. However, the most economical levels of dietary protein and amino acids in feed may not necessarily reflect the levels that are required for maximum growth, but the diets providing the largest difference between costs and returns (Costa et al. 2001a).

The optimization processes conducted in the current study did not consider the economic benefits. In addition, the nutrient requirements may differ based on the criteria chosen for production purposes (e.g. maximum $\mathrm{ADF}, \mathrm{FE}$, breast meat, edible meat or minimum abdominal fat). It is worth pointing out that the available data in the poultry literature are limited and finding a large and sufficiently homogeneous dataset for a specific genetic line of bird with the same experimental design and diet is impossible. However, modellers should look to find the most useful and reliable data based on the criteria and objectives of their study.

In conclusion, the $\mathrm{NN}$ models can act as a facilitator to understand the relationship between dietary nutrients (protein and lysine) and chicks' responses (ADG and FE) when large datasets are used. The sensitivity analysis revealed that, in all the developed models, the responses of broiler chicks were more sensitive to lysine than protein. The optimization results showed that protein and lysine requirements for maximum performance of broiler chicks after 2000 are lower and higher, respectively, compared to those reared before 2000.

The authors would like to thank the Office of Vice President of Research, Ferdowsi University of Mashhad for the funding of this project (no. 2/1652115-10-1389).

\section{REFERENCES}

Abdel-Maksoud, A., Yan, F., Cerrate, S., Coto, C., Wang, Z. \& Waldroup, P. W. (2010). Effect of dietary crude protein, lysine level and amino acid balance on performance of broilers 0 to 18 days of age. International Journal of Poultry Science 9, 21-27.

Ahmadi, H. \& Golian, A. (2010). The integration of broiler chicken threonine responses data into neural network models. Poultry Science 89, 2535-2541.

AlmQuist, H.J. (1952). Amino acid requirements of chickens and turkeys - a review. Poultry Science 31, 966-981.

Andrews, E. A. M., Morris, Q. \& Bonner, A. J. (2008). Neural networks approaches for discovering the learnable correlation between gene function and gene expression in mouse. Neurocomputing 71, 3168-3175.

Austic, R. E. (1986). Biochemical description of nutritional effects. In Nutrient Requirements of Poultry and Nutritional Research (Eds C. Fisher \& K. N. Boorman), pp. 59-77. London: Butterworths. 
Barboza, W. A., Rostagno, H.S., Albino, L. F. T. \& Rodrigues, P. B. (2000). Lysine levels for broiler chickens from 22 to 40 and 42 to 48 days of age (Níveis de Lisina para Frangos de Corte de 22 a 40 e 42 a 48 dias de Idade). Revista Brasileira de Zootecnia 29, 1091-1097. (In Spanish).

BOOMGAARDT, J. \& BAKER, D. H. (1973). The lysine requirement of growing chicks fed sesame meal-gelatin diets at three protein levels. Poultry Science 52, 586-591.

Corzo, A. \& KIDD, M. T. (2004). Starter dietary lysine level and strain cross effects on performance and carcass traits of broiler females. Revista Brasileira de Ciência Avícola 6 , 93-97.

Costa, E. F., Miller, B. R., Houston, J.E. \& Pesti, G. M. (2001a). Production and profitability responses to alternative protein sources and levels in broiler rations. Journal of Agricultural and Applied Economics 33, 567-581.

Costa, F. G. P., Rostagno, H. S., Albino, L. F. T., Gomes, P. C. \& Toledo, R. S. (2001b). Dietary lysine levels for broilers chickens from 1 to 21 and 22 to 40 days of age (Níveis Dietéticos de Lisina para Frangos de Corte de 1 a 21 e 22 a 40 Dias de Idade). Revista Brasileira de Zootecnia 30, 1490-1497.

Costa, F. G. P., Rostagno, H. S., Albino, L. F. T., Gomes, P. C., Toledo, R.S. \& de Vargas Junior, J. G. (2001C). Dietary crude protein levels for broilers chickens from 1 to 21 and 22 to 42 days of age (Níveis Dietéticos de Proteína Bruta para Frangos de Corte de 1 a 21 e 22 a 42 Dias de Idade). Revista Brasileira de Zootecnia 30, 14981505.

D'Mello, J.P. F. (1994). Amino Acids in Farm Animal Nutrition. Wallingford, Oxon, UK: CAB International.

Dozier, W. A., Moran, E. T. III Jr. \& KidD, M. T. (2001). Comparisons of male and female broiler responses to dietary threonine from 42 to 56 days of age. Journal of Applied Poultry Research 10, 53-59.

FANCHER, B. I. (2006). Feeding the Modern Broiler: CostEffective Amino Acid Levels. Vol. 2, No. 2. Huntsville, AL: Aviagen Inc.

Faridi, A., Mottaghitalab, M. \& Ahmadi, H. (2012). Sensitivity analysis of an early egg production predictive model in broiler breeders based on dietary nutrient intake. Journal of Agricultural Science, Cambridge 150, 87-93.

Faridi, A., Mottaghitalab, M., Darmani-Kuhl, H., France, J. \& AHMADI, H. (2011). Predicting carcass energy content and composition in broilers using the group method of data handling-type neural networks. Journal of Agricultural Science, Cambridge 149, 249-254.

Flachowsky, G., Chesson, A. \& Aulrich, K. (2005). Animal nutrition with feeds from genetically modified plants. Archives of Animal Nutrition 59, 1-40.

Gous, R. M. \& Morris, T. R. (1985). Evaluation of a diet dilution technique for measuring the response of broiler chickens to increasing concentrations of lysine. British Poultry Science 26, 147-161.

HAN, Y. \& BAKER, D. H. (1991). Lysine requirements of fastand slow-growing broiler chicks. Poultry Science $\mathbf{7 0 ,}$ 2108-2114.
HAN, Y. \& BAKER, D. H. (1993). Effect of sex, heat stress, body weight and genetic strain on the lysine requirement of broiler chicks. Poultry Science 72, 701-708.

Hewitt, D. \& Lewis, D. (1972). The amino acid requirements of the growing chick. 1. Determination of amino acid requirements. British Poultry Science 13, 449-463.

Hunter, A., Kennedy, L., Henry, J. \& Ferguson, I. (2000). Application of neural networks and sensitivity analysis to improved prediction of trauma survival. Computer Methods and Programs in Biomedicine 62, 11-19.

KIDD, M.T. \& FANCHER, B.I. (2001). Lysine needs of starting chicks and subsequent effects during the growing period. Journal of Applied Poultry Research 10, 385-393.

Kidd, M. T., Kerr, B. J., Firman, J. D. \& Boling, S. D. (1996). Growth and carcass characteristics of broilers fed lowprotein, threonine supplemented diets. Journal of Applied Poultry Research 5, 180-190.

LATSHAW, J. D. (1993). Dietary lysine concentrations from deficient to excessive and the effects on broiler chicks. British Poultry Science 34, 951-958.

LeCLERCQ, B. (1998). Specific effects of lysine on broiler production: Comparison with threonine and valine. Poultry Science 77, 118-123.

Lopez, G. \& LeESON, S. (1995). Response of broiler breeders to low-protein diets. 1. Adult breeder performance. Poultry Science 74, 685-695.

LOU, W. \& NAKAI, S. (2001). Artificial neural network-based predictive model for bacterial growth in a simulated medium of modified-atmosphere-packed cooked meat products. Journal of Agricultural and Food Chemistry 49, 1799-1804.

Lucas, D. M., Taylor, M. L., Hartnell, G. F., Nemeth, M. A., GlenN, K. C. \& DAVIS, S. W. (2007). Broiler performance and carcass characteristics when fed diets containing lysine maize (LY038 or LY038 MON 810), control, or conventional reference maize. Poultry Science 86, 2152-2161.

MACLEOD, M. G. (2000). Modelling the utilization of dietary energy and amino acids by poultry. In Feeding Systems and Feed Evaluation Models (Eds M. K. Theodorou \& J. France), pp. 393-412. Wallingford, Oxon, UK: CABI.

MERCER, L.P. (1982). The quantitative nutrient-response relationship. Journal of Nutrition 112, 560-566.

Morris, T. R., Al-Azzawi, K., Gous, R. M. \& Simpson, G. L. (1987). Effects of protein concentration on responses to dietary lysine by chicks. British Poultry Science 28, 185195.

National Research Council (1994). Nutrient Requirements of Poultry. 9th Revised Edn. Washington, D.C.: National Academy Press.

Safamehr, A., Azgani, A. \& Mehmannavaz, Y. (2008). Effect of lysine $\mathrm{HCl}$ supplementation on performance and carcass characteristics of Ross broilers. Research Journal of Biological Science 3, 1197-1201.

Sas Institute Inc. (1999). SAS/STAT User's Guide. Version 8. Cary, NC: SAS Institute Inc.

Statsoft (2009). Statistica Data Analysis Software System. Version 7.1. Tulsa, OK: StatSoft Inc. 
Sterling, K. G., Peesti, G. M. \& Bakalli, R. I. (2002). The response of broiler chicks to dietary lysine and crude protein with different amino acid profiles (abstract). Poultry Science 81(Suppl. 1), 26.

Sterling, K. G., Pesti, G. M. \& Bakalli, R. I. (2003). Performance of broiler chicks fed various levels of dietary lysine and crude protein. Poultry Science $\mathbf{8 2}$, 1939-1947.

Sterling, K. G., Pesti, G.M. \& Bakalli, R. I. (2006). Performance of different broiler genotypes fed diets with varying levels of dietary crude protein and lysine. Poultry Science 85, 1045-1054. 